\title{
STRUCTURAL DESIGN AND COST ANALYSIS OF A LEED-CERTIFIED BUILDING
}

\author{
Michael Grams, Laura Ghloum, David Hakobyan, Mariam Hanin, Kamal Khalil, \\ Tadeh Zirakian* and David Boyajian \\ Department of Civil Engineering and Construction Management, \\ California State University, Northridge, California, United States of America
}

*Corresponding Author: Phone: +1-818-677-7718 \& E-mail: tadeh.zirakian@csun.edu

\begin{abstract}
Sustainable building design is paving the road for future building designs. In the research presented, a group of diverse civil engineering undergraduates designed a Leadership in Energy and Environmental Design certified building and computed its cost analysis. A comparison between the cost of a conventional building versus a LEED certified building is presented to provide a realistic view of the cost of environmentally friendly buildings. The cost analysis compares between traditional materials, and typical building methods versus recycled materials, and new sustainable designs. Among these topics the group also discusses the Leadership in Energy and Environmental Design certification standards and the green features that are added to the conventional building to make it an environmentally friendly building. In the research, it is illustrated that a green building is more costly in the present time but can pay itself off in the future as it consists of several cost saving features. Although sustainable building design requires detailed planning, and costly material, it is beneficial for the environment and society.
\end{abstract}

Keywords: Environmental design, LEED, Sustainable building, Recycled materials, Cost analysis

Cite this Article: Michael Grams, Laura Ghloum, David Hakobyan, Mariam Hanin, Kamal Khalil, Tadeh Zirakian and David Boyajian, Structural Design and Cost Analysis of a LEED-Certified Building, International Journal of Civil Engineering and Technology (IJCIET), 12(4), 2021, pp. 73-81.

https://iaeme.com/Home/issue/IJCIET?Volume $=12 \&$ Issue $=4$

\section{INTRODUCTION}

The future of structural design is heading towards environmentally friendly building designs. The process of designing a green building is composed of several stages such as the architectural design, the structural design, and the cost analysis of the project. In the report, a group of civil engineering undergraduate students present a research and design of a three-story LEED certified green building. The group starts with the architectural design stage, which includes the floor and roof designs. After that, the structural design of the building is presented 
and modeled on the RAM structural system. In the structural design stage, the group added several environmentally friendly features that are taken from the Leadership in Energy and Environmental Design program. The green features are added to make the building eco-friendly and sustainable. Lastly, a cost analysis comparison is made between a conventional building and a green alternative to help pave the way for future green building designs.

\section{ARCHITECTURAL FEATURES}

For the architectural layout of this project, the team was given a set of guidelines to follow when designing the layout of this building. The first requirement is that the building must be a three-story building and have a minimum floor size of at least 2000 square feet. Second, each floor must have a kitchen, living room, dining room, storage, three bathrooms, and three bedrooms. Third, the building had to be designed on a plot located in the greater Los Angeles area. The last requirement is to incorporate as many green building features in the design as possible.

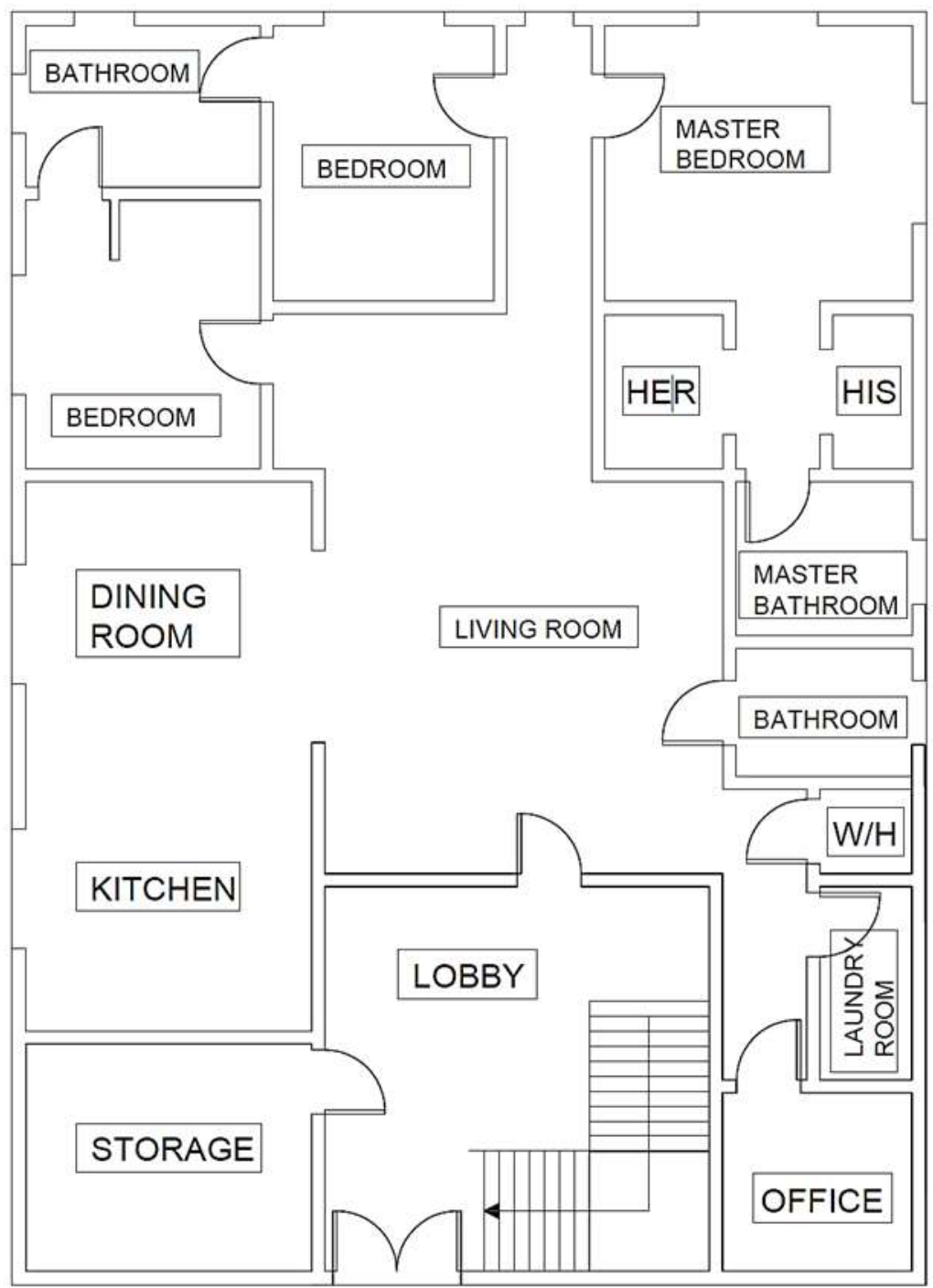

Figure 1 Typical Floor Plan

Along with these requirements, the group added additional design features that would make the building more modern. One of these features was to design each floor to be an open space concept. This was done by making the living room the center of the floor plan and having all 
other rooms branch off from the living room (shown in Fig. 1). Additionally, a 3-story tall glass curtain wall at the entrance/stairwell of the building was added to keep with the modern theme (shown in Fig. 2). The curtain wall was added not only for its aesthetics but to allow natural light into the building. Following this modern theme, a large green roof deck was incorporated into the design. This not only helps the building to be environmentally friendly but also gives the residents a safe outdoor environment to enjoy.

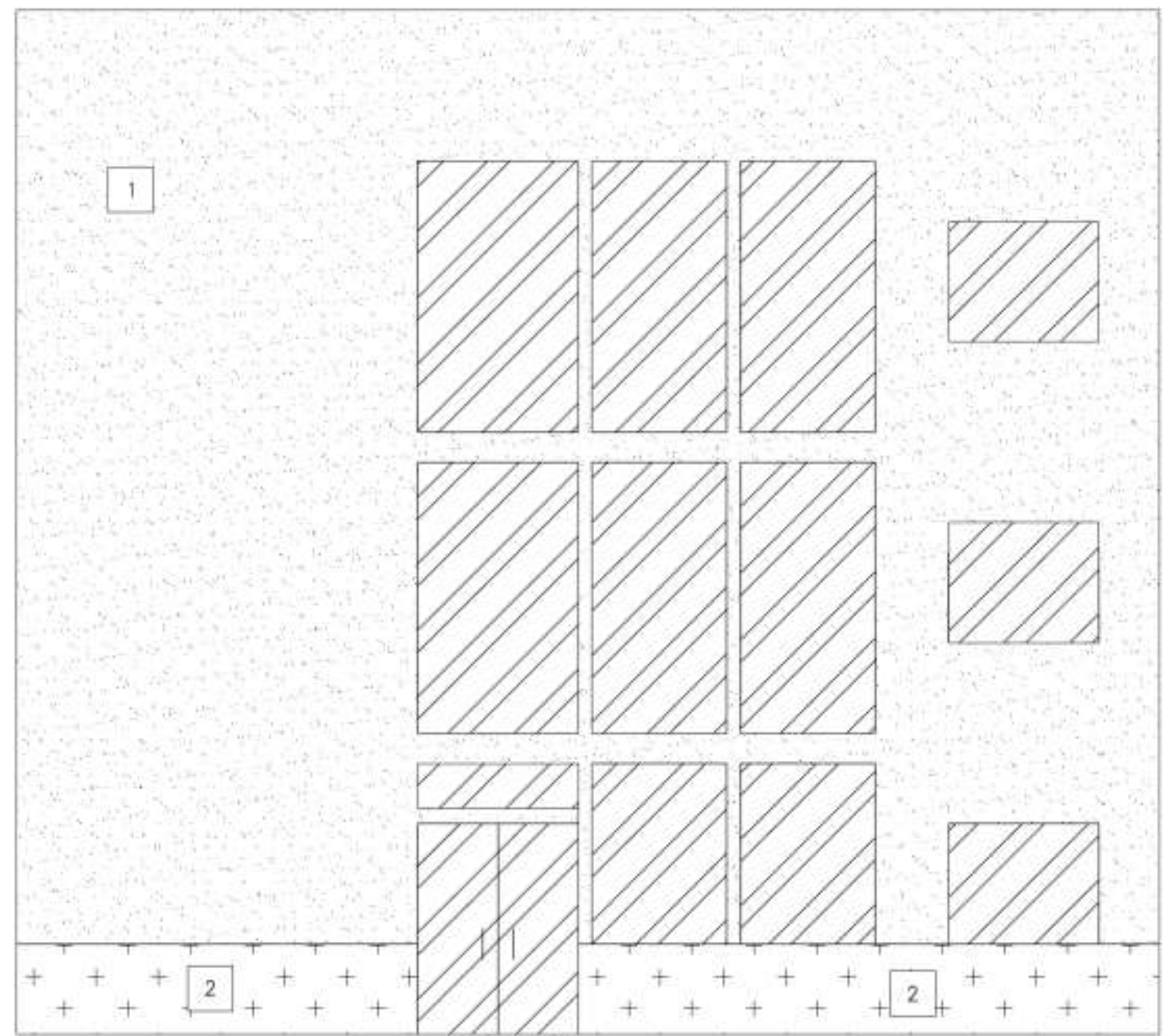

Figure 2 Exterior elevation views

\section{STRUCTURAL DESIGN}

There are two guidelines to follow. The first guideline is that the building must be designed as a steel frame structure. This will eliminate the use of any bearing walls in the design, as mentioned in Segui's Steel Design [9]. Second, the lateral resisting system must be designed using a moment frame, which excludes the use of braced frames (shown in Fig. 6).

Similar to the architectural design, additional features to the structural design were added. The first is that the floors and roof deck will consist of a five-inch minimum concrete topping on a Verco decking pan by following McCormack's Design of Reinforced Concrete [8]. This will minimize the deflection of the floor and withstand the large anticipated live load required by ASCE 7-16 [5]. Second, all columns will be made of the same section from ground level to the roof level (shown in Fig. 3) in accordance with ACI 318 code [2]. This will reduce the additional cost associated with having welders on site. Thirdly, since the frame of the building 
is a strong steel frame, a lightweight wall system will be used to reduce the weight of the structure. This is done by using cold formed steel stud walls throughout the building. These walls will be designed to the AISI manuals requirements [4]. In using cold formed steel studs, each steel stud weighs approximately 0.2 plf compared to a typical $2 \times 6$ that weighs nearly 3 plf. The final structural feature is to have bolted connections now frames. Again, this feature was added to reduce the need for on-site welding. The bolted connections have been designed by following the guidelines listed in the AISC: Steel Construction Manual [3].

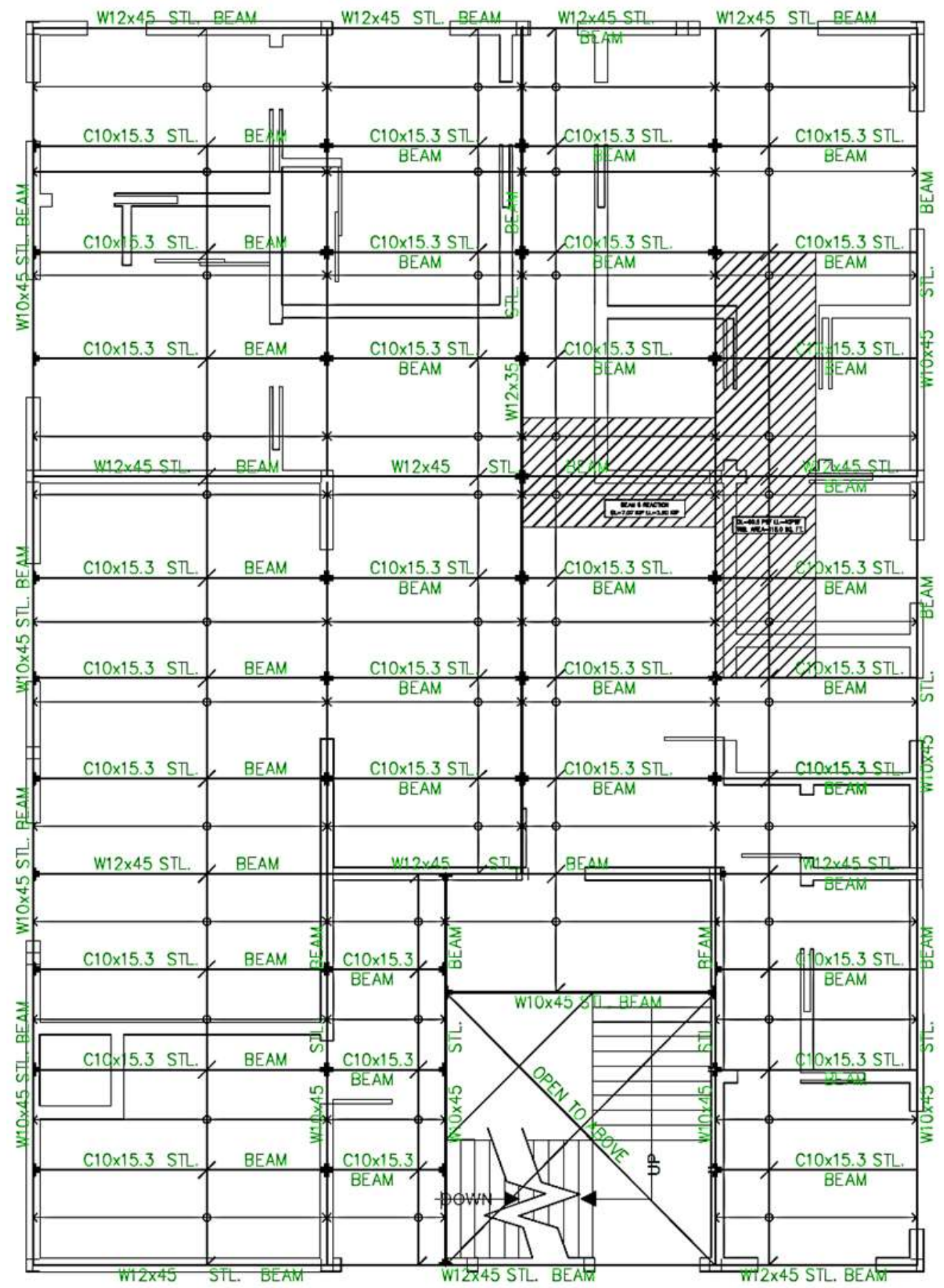

Figure 3 Typical structural floor framing plan 

and David Boyajian

\section{DESIGN FOR SUSTAINABILITY AND LEED CERTIFICATION}

In the United States, buildings account for 40 percent of energy consumption and 39 percent of energy-related carbon dioxide emissions annually, according to the U.S. Energy information Administration [11]. This calls for the demand of more sustainable working and living conditions by retrofitting and designing new buildings to be LEED certified, as mentioned by Joseph G. Allen in his article [1].

LEED stands for Leadership in Energy and Environmental Design, which is an environmentally friendly certification program that is used worldwide. It was developed by the non-profit U.S. Green Building Council, focusing on the construction and maintenance of buildings to help the building owners become environmentally responsible. Whereas Green Buildings are those that have environmental-friendly and resources-efficient features that help in preserving resources and keeping the planet clean.

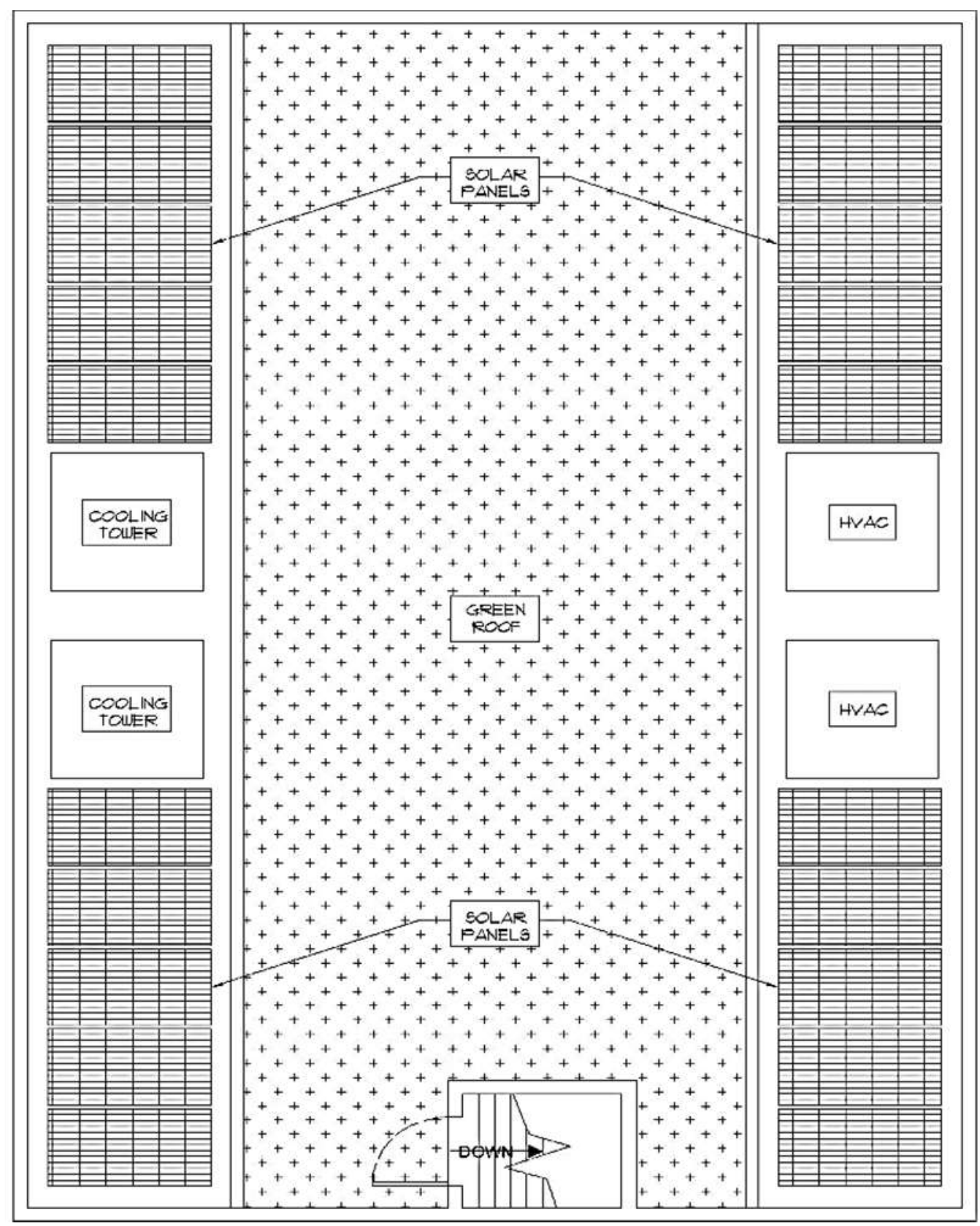

Figure 4 Roof plan 


\begin{tabular}{|l|l|l|lll|}
\hline 0 & 0 & 6 & Innovation & 6 \\
\hline 0 & 0 & 5 & Cnat & Innovation & 5 \\
\hline 0 & 0 & 1 & Cnast & LEED Accredited Professional & 1 \\
\hline
\end{tabular}

\begin{tabular}{|l|l|l|lll|}
\hline 0 & 0 & 4 & Regional Priority & 4 \\
\hline 0 & 0 & 1 & Ondt & Regional Prionity: Specific Credit & 1 \\
\hline 0 & 0 & 1 & Cndt & Regional Priority: Specific Credit & 1 \\
\hline 0 & 0 & 1 & Cnat & Regional Priority: Specific Credit & 1 \\
\hline 0 & 0 & 1 & Cnast & Regional Priority: Specific Credit & 1 \\
\hline
\end{tabular}

\begin{tabular}{l|l|l|l|l|l}
73 & 5 & 32 & TOTALS & Possible Points: & 110
\end{tabular}

Certified: 40 to 49 points, Silver: 50 to 59 points, Gold: 80 to 78 points, Platinum: 80 to 110

Figure 5 LEED project checklist

For the designed building, the group achieved a Gold LEED Certification Status, as seen in Fig. 5. Many green features are added to the designed building, but the 3 main features contributing to reduced energy waste are the rain barrels, a green roof, and the solar panels, detailed by Sam Kubba [7].

The U.S. Environmental Protection Agency stated for every inch of rainfall in L.A. 3.8 billion gallons of runoff drain to the ocean [13]. By taking advantage of rain gutters, rain can be diverted into and stored in rain barrels. The benefits they provide are immense, such as acting as a water source in a drought or when there are set watering restrictions. In addition, reducing the amount of runoff pollution with the ability to water the soil and plants, reduces the water bill. This makes the house more cost efficient.

Whereas, a green roof was installed on the roof, shown in Fig. 4. A green roof serves as an insulation to the building. It reduces the temperature of the roof and, therefore, the building itself. The reduction in cooling loads also helps reduce greenhouse gas emissions from fossil fuel combustion associated with the use of HVAC equipment, resulting in energy cost savings. While the solar panels are a great way to offset energy costs, reduce the environmental impact of the designed building, and provide a host of other benefits such as earning tax credits and rebates.

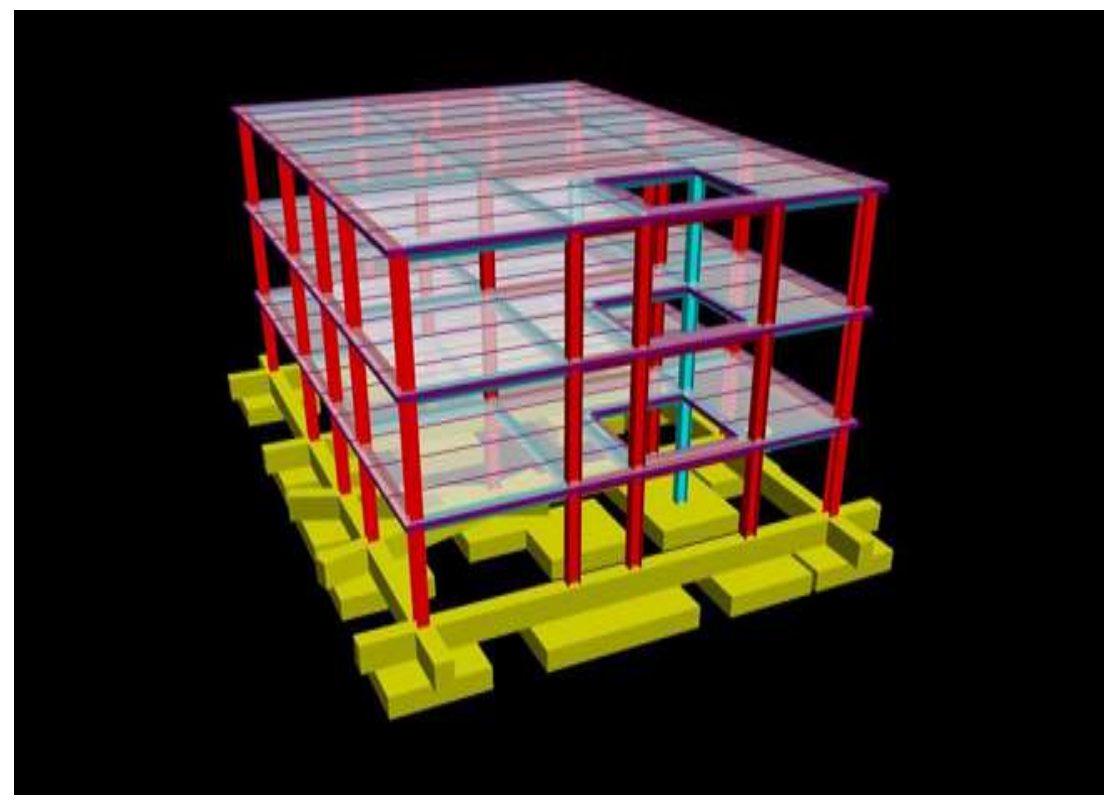

Figure 6 RAM structural model of the green building 


\section{COST ANALYSIS}

It is evident that a green building will incur more cost than an average building in its stead. However, for a client it is important to provide a cost analysis. The group has been given initial conditions that may or may not affect a similar building. For example, the first criteria for a LEED certified building have to do with location. The location must have easy access to public transport as well as bicycle facilities to achieve points towards a certification [6]. Since this was an initial condition that would not be in the control of an engineer, the group decided not to incorporate the cost of real estate. This condition lowered the cost of the building.

The normal and LEED cost of the building was calculated using the program Rs Means. This tool allows a rough estimate of construction costs that includes labor, material, and equipment costs with each facet of the building. Some of the things included in the cost analysis are steel members, structural concrete, drywall, plumbing, electrical, etc. Table 1 illustrates the cost analysis of the normal building without LEED features and Table 2 illustrates the cost of the LEED designed building.

Table 1 Conventional building costs

\begin{tabular}{|r|r|r|}
\hline Unit & Extended Total & Extended Total 0\&P \\
\hline Ea. & $\$ 3,671.25$ & $\$ 4,298.94$ \\
\hline Ea. & $\$ 5,233.22$ & $\$ 6,371.48$ \\
\hline Ea. & $\$ 1,077.12$ & $\$ 1,681.92$ \\
\hline Ea. & $\$ 42,663.20$ & $\$ 56,494.80$ \\
\hline Ea. & $\$ 3,403.82$ & $\$ 4,945.57$ \\
\hline Ea. & $\$ 12,365.04$ & $\$ 16,657.38$ \\
\hline Ea. & $\$ 6,366.24$ & $\$ 9,049.92$ \\
\hline Ea. & $\$ 872.16$ & $\$ 1,065.36$ \\
\hline S.Y. & $\$ 1,391.67$ & $\$ 1,786.47$ \\
\hline L.F. & $\$ 41,230.00$ & $\$ 56,176.00$ \\
\hline L.F. & $\$ 2,748.00$ & $\$ 3,746.00$ \\
\hline Ea. & $\$ 1,193.52$ & $\$ 1,509.74$ \\
\hline & $\$ 74,018.78$ & $\$ 933,031.09$ \\
\hline
\end{tabular}

Table 2 LEED Building Costs

\begin{tabular}{r|r|r}
\hline Unit & \multicolumn{1}{|c}{ Extended Total } & Extended Total 0\&P \\
\hline Ea. & $\$ 1,077.12$ & $\$ 1,681.92$ \\
\hline Ea. & $\$ 42,663.20$ & $\$ 56,494.80$ \\
\hline Ea. & $\$ 3,403.82$ & $\$ 4,945.57$ \\
\hline Ea. & $\$ 12,365.04$ & $\$ 16,657.38$ \\
\hline Ea. & $\$ 6,366.24$ & $\$ 9,049.92$ \\
\hline Ea. & $\$ 872.16$ & $\$ 1,065.36$ \\
\hline S.Y. & $\$ 1,391.67$ & $\$ 1,786.47$ \\
\hline L.F. & $\$ 1,230.00$ & $\$ 56,176.00$ \\
\hline L.F. & $\$ 2,748.00$ & $\$ 3,746.00$ \\
\hline Ea. & $\$ 1,193.52$ & $\$ 1,509.74$ \\
\hline Ea. & $\$ 23,988.00$ & $\$ 31,440.00$ \\
\hline Ea. & $\$ 5,699.00$ & $\$ 6,450.00$ \\
\hline & $\$ 787,200.88$ & $\$ 992,743.69$ \\
\hline
\end{tabular}


As shown in Tables 1 and 2, the cost of the Normal Building and the LEED building is $\$ 933,031.09$ and $\$ 992,743.69$, respectively. This results in a $6.3 \%$ increase from a normal building cost to a LEED building. The elements that increased the cost were the solar panels, rain collection barrel, cooling tower, and the additional insulation for soundproofing. This was mentioned by the article examining the LEED certification in terms of construction costs [10]. However, these inclusions also reduce cost over time. The normal building uses $557 \mathrm{KWh}$ per month, while the LEED building uses $255 \mathrm{KWh}$ per month, as mentioned by the U.S Energy Information Administration [11]. This, including water savings, results in $\$ 3,317.98$ in savings per year. In 18 years, the cost of LEED features would be paid off.

\section{EDUCATIONAL OBJECTIVES}

The project provides details about architectural design, consideration, features, structural design, design for sustainability, cost analysis, and LEED certification for an environmentally friendly building. In addition, the study discusses the advantages and features structural design and cost analysis of a LEED certified building as an undergraduate project. It aims to instil the following virtues and skills, diversity, teamwork, leadership, creativity, innovation, and ethics. The world is changing, especially in the construction industry due to the increasing climatic changes. The building field causes significant pollution caused by considerable consumption of energy, extensive use of natural resources, and production of waste products. Therefore, engineers should develop suitable building technologies and designs that minimize environmental pollution associated with the conventional construction practices. Student engineers should develop some appropriate skills during undergraduate studies to help contribute to the fight against pollution caused by the construction industry. Therefore, the project intends to help students develop innovative and creative skills that can be employed to design suitable systems and designs that can help reduce environmental pollution caused by the construction industry.

\section{CONCLUSION}

The design process of a green building requires several stages such as the architectural design and structural design stages. In addition, a cost analysis is important to compare the cost of a conventional building to the cost of a LEED certified green to show how a green alternative is beneficial in the long run. In the structural design, several green features are added to the building such as solar panels, rain barrels, and vegetation on the roof. The green features are added to minimize the waste of vital resources such as water and electricity. Although the LEED certified building is a costly alternative, the building's cost will be paid off in eight years and about three thousand dollars will be saved annually after the cost is paid off. Therefore, the green building design is an excellent choice for future projects because the design not only saves vital resources and helps in saving the environment, but also gets paid off in the long run.

\section{ACKNOWLEDGEMENT}

The student research team would like to express their sincere appreciation for the support provided by Dr. Tadeh Zirakian and Dr. David Boyajian, Professors of Civil Engineering in the Department of Civil Engineering and Construction Management at California State University, Northridge, U.S.A. 
Michael Grams, Laura Ghloum, David Hakobyan, Mariam Hanin, Kamal Khalil, Tadeh Zirakian and David Boyajian

\section{REFERENCES}

[1] Allen, Joseph G., et al. "Green Buildings and Health." Current Environmental Health Reports 2.3 (2015).

[2] American Concrete Institute Committee 318. Building Code Requirements for Structural Concrete (ACI 318-19). 2019.

[3] American Insitute Steel Committee. Steel Construction Manual (15th Edition). AISC, n.d.

[4] American Iron and Steel Institute. AISI Standard - North American Standard for Cold-Formed Steel Framing - General Provisions. AISI, 2007.

[5] American Society of Civil Engineers. ASCE 7-16 Minimum Design Loads and Associated Criteria for Buildings and Other Structures. American Society of Civil Engineers, 2017.

[6] Hooks, Julian. LEED Certification Requirements, Rating System, and Benefits. 11 September 2020.

[7] Kubba, Sam. LEED Practices, Certification, and Accreditation Handbook. ButterworthHeinemann, 2009.

[8] McCormack, Jack C. and Russell H. Brown. Design of Reinforced Concrete. Wiley, 2016.

[9] Segui, William T. Steel Design, Fifth Edition. Stamford: Global Engineering, 2013.

[10] Uğur, Latif Onur and Neşe Leblebici. "An examination of the LEED green building certification system in terms of construction costs." Renewable and Sustainable Energy Reviews (2017).

[11] United States Energy Information Administration. 2019. 